University of Nebraska - Lincoln

DigitalCommons@University of Nebraska - Lincoln

Faculty Publications: Department of Entomology

Entomology, Department of

2004

\title{
Effect of Environment on Resistance to the European Corn Borer (Lepidoptera: Crambidae) in Maize
}

\author{
David B. Willmot \\ Agilent Technologies, Inc., david_willmot@agilent.com \\ Bruce E. Hibbard \\ USDA-ARS, bruce.hibbard@ars.usda.gov \\ Larry L. Darrah \\ USDA-ARS \\ Linda M. Pollak \\ USDA-ARS \\ Kevin Montgomery \\ Golden Harvest Research
}

See next page for additional authors

Follow this and additional works at: https://digitalcommons.unl.edu/entomologyfacpub

Part of the Entomology Commons

Willmot, David B.; Hibbard, Bruce E.; Darrah, Larry L.; Pollak, Linda M.; Montgomery, Kevin; Pratt, Richard C.; Abel, Craig A.; Hawk, James A.; Weldekidan, Tecle; and Foster, John E., "Effect of Environment on Resistance to the European Corn Borer (Lepidoptera: Crambidae) in Maize" (2004). Faculty Publications: Department of Entomology. 449.

https://digitalcommons.unl.edu/entomologyfacpub/449

This Article is brought to you for free and open access by the Entomology, Department of at DigitalCommons@University of Nebraska - Lincoln. It has been accepted for inclusion in Faculty Publications: Department of Entomology by an authorized administrator of DigitalCommons@University of Nebraska - Lincoln. 


\section{Authors}

David B. Willmot, Bruce E. Hibbard, Larry L. Darrah, Linda M. Pollak, Kevin Montgomery, Richard C. Pratt, Craig A. Abel, James A. Hawk, Tecle Weldekidan, and John E. Foster 


\title{
Effect of Environment on Resistance to the European Corn Borer (Lepidoptera: Crambidae) in Maize
}

\author{
DAVID B. WILLMOT, ${ }^{1,2}$ BRUCE E. HIBBARD,${ }^{1}$ LARRY L. DARRAH,${ }^{1}$ LINDA M. POLLAK, ${ }^{3}$ \\ KEVIN MONTGOMERY, ${ }^{4}$ RICHARD C. PRATT, ${ }^{5}$ CRAIG A. ABEL,${ }^{6}$ JAMES A. HAWK, ${ }^{7}$ \\ TECLE WELDEKIDAN, ${ }^{7}$ AND JOHN E. FOSTER ${ }^{8}$
}

\begin{abstract}
J. Econ. Entomol. 97(5): 1745-1751 (2004)
ABSTRACT The European corn borer, Ostrinia nubilalis (Hübner) (Lepidoptera: Crambidae), is a major pest of maize, Zea mays L., in many temperate parts of the world. Genotype-by-environment interaction effects can make relative performance unpredictable and may hamper selection for resistance to European corn borer. The objective of this study was to determine the effect of environment on genotypic reaction to European corn borer resistance in maize. A set of 12 maize inbred lines was chosen to represent a range of European corn borer responses. Eleven testing environments ranged from Delaware, Ohio, Illinois, Iowa, Nebraska, Missouri, to Mississippi. For length of stalk tunneling, environmental and genotypic main effects (estimated by restricted maximum likelihood) were $>20$ - and 10-fold larger than their interaction effect, respectively. Length of tunneling means for genotypes (across environments) ranged from 10.1 to $35.4 \mathrm{~cm}$. Several putatively resistant genotypes grouped with the susceptible checks, B73 and Mol7. By breaking factors and the interaction into single degree of freedom components, we observed that GEMS-0001 had significant crossover interactions toward less susceptibility in both Mississippi and the Nebraska environments. Environments displaying several crossover interactions indicated that European corn borer screening at these sites would not necessarily apply to other locations, whether due to small differences in experimental conduct and/or environmental effects. The five most resistant genotypes were fairly consistent across environments. Because all environments except Illinois used larvae from the same insectary, and these environments differed in damage intensity and rankings, it is unlikely that insect biotype was a factor contributing to genotype-by-environment effects.
\end{abstract}

KEY WORDS Ostrinia nubilalis, plant resistance, genotype-by-environment interaction, genotype $\times$ environment stability, insect resistance

EUROPEAN CORN BORER, Ostrinia nubilalis (Hübner), damage is a common problem in susceptible maize, Zea mays L., hybrids (Martin and Hyde 2001). First

\footnotetext{
This article reports the results of research only. Mention of a proprietary product does not constitute an endorsement or recommendation for its use by the USDA, Golden Harvest company, The Ohio State University, University of Delaware, or University of Nebraska.

${ }^{1}$ USDA-ARS, Plant Genetics Research Unit, 205 Curtis Hall, University of Missouri, Columbia, MO 65211-7020.

${ }^{2}$ Current address: Agilent Technologies, Inc., Gene Expression Division, 2850 Centerville Rd. 3J8, Wilmington, DE 19808 (e-mail: davidwillmot@agilent.com).

${ }^{3}$ US̄DA-ARS, Corn Insects and Crop Genetics Research Unit, 1405 Agronomy Bldg., Iowa State University, Ames, IA 50011-1010.

${ }^{4}$ Golden Harvest Research, R.R. \#3, Box 257, Clinton, IL 61727.

${ }^{5}$ Department of Horticulture and Crop Science, Ohio Agricultural Research and Development Center, The Ohio State University, Wooster, OH 44691-4096.

${ }^{6}$ USDA-ARS, Southern Insect Management Research Unit, 141 Experiment Station Rd., Stoneville, MS 38776-0000.

${ }^{7}$ University of Delaware, Department of Plant and Soil Science, 136 Townsend Hall, Newark, DE 19716.

${ }^{8}$ Department of Entomology, 312F PI Bldg., University of Ne-
} braska, Lincoln, NE 68583-0816. generation larvae may cause yield reductions with earlier or heavier infestations (Bode and Calvin 1990) or when exacerbated by drought stress (Davis and Pedigo 1991, Godfrey et al. 1991), whereas the second generation larvae may cause significant economic damage as they tunnel through stalks, ear shanks, and husks. Translocation is disrupted, stalk and ear rot organisms are introduced (Gatch and Munkvold 2002, Magg et al. 2002), and plants often lodge, leaving the ear unharvestable on or near the ground (Mason et al. 1996).

Native host plant resistance to the European corn borer (Guthrie et al. 1960, Guthrie and Russell 1989) can complement control measures with Bacillus thuringiensis Berliner $(\mathrm{Bt})$ or other transgenic corn products (Martin and Hyde 2001). Hybrids that differ only by the presence or absence of the $\mathrm{Bt}$ transgene allow better estimates of yield reductions caused by European corn borers than was possible previously (Traore et al. 2000, Baute et al. 2002). The reduction of toxic ear rot organisms such as Aspergillus flavus Link and Fusarium moniliforme J. Sheld. has been recognized as 
Table 1. Maize genotypes tested for European corn borer resistance in 11 environments

\begin{tabular}{|c|c|c|c|}
\hline Code & Genotype & Description & Reference \\
\hline G1 & GEMS-0001 & $\begin{array}{l}\mathrm{BC}_{4} \text { of a Peruvian donor by an Iowa Stiff-Stalk Synthetic } \\
\text { line: PI } 503806 / 3 * / \text { B9 } 94 \text { mass selected for resistance to first } \\
\text { and second generation European corn borer }\end{array}$ & Abel and Wilson (1999), Abel et al. (2001) \\
\hline G2 & SSM34-5A91102A & $\begin{array}{l}\mathrm{S}_{5} \text { from GEMS-0001 selected for increased second } \\
\text { generation European corn borer resistance }\end{array}$ & C. A. Abel, personal communication \\
\hline G3 & DE811 & $\mathrm{S}_{6}$ from B68 (a B14 type)/ (a complex double cross) & Hawk (1985) \\
\hline G4 & Mo46 & $\mathrm{S}_{6}$ from Cravo Paulista (Brazilian SP II) / Pioneer Brand 3184 & Barry et al. (1995) \\
\hline G5 & Mo47 & $\mathrm{S}_{6}$ from Candela (Ecu 344)/Pioneer Brand 3184 & Barry et al. (1995) \\
\hline G6 & PRMO2-9 & $\begin{array}{l}\mathrm{S}_{6} \text { derived from Mo-2 ECB-2, which is from Nigerian } \\
\text { Composite } \mathrm{B} \text { that has Caribbean, Central American, and } \\
\text { Mexican germplasm }\end{array}$ & Barry et al. (1985) \\
\hline G7 & Mo48 & $\mathrm{S}_{6}$ from NC33 (PI 608538)/B52 & PI 634206 \\
\hline G8 & Mo49 & $\mathrm{S}_{6}$ of Mo ECB syn/Cargill populations// MpSWCB\#4 & PI 634207 \\
\hline G9 & NE547 & $\begin{array}{l}\mathrm{S}_{5} \text { from MBITA tropical pop from CIMMYT with multiple } \\
\text { stalk borer resistance }\end{array}$ & D’Croz-Mason et al. (2002) \\
\hline G10 & DE5 & Tested as DE(BSSS)C2-420-3-2-1-1-1 & J. Hawk, personal communication \\
\hline G11 & B73 & PI 550473 (derived from BSSS) & Russell (1972) \\
\hline G12 & Mol7 & PI 558532 (CI 187-2/C103) & Zuber (1973) \\
\hline
\end{tabular}

a major benefit from controlling insects such as European corn borer in Bt hybrids (Gatch and Munkvold 2002). Insecticide control methods are less desirable due to their unpredictable results, environmental and health impacts, and cost (Mason et al. 1996). Moreover, native host plant resistance would not incite the marketing restrictions that genetically modified products may face.

Genotype-by-environment interactions (GEI) are a common problem in plant breeding. Phenotypic stability of traits, such as resistance to European corn borer, facilitates selection, but frequently genotypes differ in their relative performance across environments. Genotypes that contribute most to GEI via crossover interactions are less desirable sources of resistance. In crossover interactions, the best genotypes differ from one location to another. The term arises from the intersecting lines that may occur when genotype reactions are plotted across environments. Quantitative trait loci studies also reflect the influence of GEI. Only a minority of chromosomal regions linked to European corn borer tunnel-feeding resistance have been significant across multiple environments (Cardinal et al. 2001, Jampatong et al. 2002). If the expression of host plant resistance or the biotype of the insect varies with environment, the selection strategy must change accordingly.

Crossa (1990) reviewed various approaches to quantifying GEI. Conventional linear regression approaches are less informative when linearity assumptions are not present. Principle component data can be difficult to interpret and favors extensive testing across environments (Romagosa and Fox 1993). Cluster analysis depends on fairly dense geographical coverage. Restricted maximum likelihood (REML) analysis can partition the causes of GEI, while estimating genetic variances and covariances for the best fit (Littell et al. 1996, Yang 2002).

The objectives of this study were to (1) determine the effect of environment on resistance to European corn borer in a set of resistant and susceptible maize

Table 2. Environments used for European corn borer resistance tests

\begin{tabular}{|c|c|c|c|c|c|c|c|c|c|}
\hline \multirow[t]{2}{*}{ Code } & \multirow[t]{2}{*}{ Environment } & \multicolumn{2}{|c|}{$\begin{array}{c}\text { Pre-LD1 to early silk } \\
\text { stage }^{a}\end{array}$} & \multicolumn{2}{|c|}{$\begin{array}{l}\text { Early silk to milk } \\
\text { stage }^{b}\end{array}$} & \multicolumn{2}{|c|}{$\begin{array}{l}\text { Milk stage to } \\
\text { maturity }\end{array}$} & \multicolumn{2}{|c|}{ Coordinates } \\
\hline & & H.U. ${ }^{d}$ & Rain $(\mathrm{mm})$ & H.U. & Rain $(\mathrm{mm})$ & H.U. & Rain $(\mathrm{mm})$ & Lat. N & Long.W \\
\hline E1 & Columbia, $\mathrm{MO}^{e}$ & 757 & 79 & 539 & 40 & 849 & 179 & $38^{\circ} 58^{\prime}$ & $92^{\circ} 22^{\prime}$ \\
\hline $\mathrm{E} 2$ & Tipton, MO & $\mathrm{n} / \mathrm{a}$ & $\mathrm{n} / \mathrm{a}$ & $\mathrm{n} / \mathrm{a}$ & $\mathrm{n} / \mathrm{a}$ & $\mathrm{n} / \mathrm{a}$ & $\mathrm{n} / \mathrm{a}$ & $38^{\circ} 43^{\prime}$ & $92^{\circ} 54^{\prime}$ \\
\hline E3 & HF Ames, IA & 700 & 136 & 491 & 148 & 773 & 77 & $42^{\circ} 2^{\prime}$ & $93^{\circ} 48^{\prime}$ \\
\hline $\mathrm{E} 4$ & PI Ames, IA & 700 & 136 & 491 & 148 & 773 & 77 & $42^{\circ} 2^{\prime}$ & $93^{\circ} 48^{\prime}$ \\
\hline E5 & Stoneville, MS & 616 & 77 & 525 & 15 & 916 & 123 & $33^{\circ} 32^{\prime}$ & $90^{\circ} 5^{\prime}$ \\
\hline E6 & Elizabeth, MS & $\mathrm{n} / \mathrm{a}$ & $\mathrm{n} / \mathrm{a}$ & $\mathrm{n} / \mathrm{a}$ & $\mathrm{n} / \mathrm{a}$ & $\mathrm{n} / \mathrm{a}$ & $\mathrm{n} / \mathrm{a}$ & $33^{\circ} 32^{\prime}$ & $89^{\circ} 48^{\prime}$ \\
\hline E7 & Newark, DE & 670 & 24 & 508 & 24 & 804 & 108 & $39^{\circ} 33^{\prime}$ & $75^{\circ} 46^{\prime}$ \\
\hline E8 & Wooster, $\mathrm{OH}^{e}$ & 640 & 27 & 474 & 37 & 742 & 126 & $40^{\circ} 47^{\prime}$ & $81^{\circ} 55^{\prime}$ \\
\hline E9 & Clinton, IL & 795 & 30 & 589 & 95 & 873 & 231 & $40^{\circ} 2^{\prime}$ & $88^{\circ} 52^{\prime}$ \\
\hline E10 & Pekin, IL & $\mathrm{n} / \mathrm{a}$ & $\mathrm{n} / \mathrm{a}$ & $\mathrm{n} / \mathrm{a}$ & $\mathrm{n} / \mathrm{a}$ & $\mathrm{n} / \mathrm{a}$ & $\mathrm{n} / \mathrm{a}$ & $40^{\circ} 31^{\prime}$ & $89^{\circ} 43^{\prime}$ \\
\hline E11 & Ithica, NE & 728 & 7 & 511 & 26 & 804 & 167 & $41^{\circ} 23^{\prime}$ & $96^{\circ} 30^{\prime}$ \\
\hline
\end{tabular}

Lat., latititude; Long., longitude; n/a, data not available.

${ }^{a}$ Four-week period ending $10 \mathrm{~d}$ before peak flowering covering whorl infestation and feeding.

${ }^{b}$ The following $3 \mathrm{wk}$ beginning $10 \mathrm{~d}$ before European corn borer infestation at anthesis and including pest establishment.

${ }^{c}$ Five-week period covering the European corn borer tunneling period.

${ }^{d}$ Heat units with a base of $10^{\circ} \mathrm{C}$ and a ceiling of $30^{\circ} \mathrm{C}$.

${ }^{e}$ Includes supplemental irrigations before flowering. 
Table 3. Restricted max likelihood mixed model analysis of variance on European corn borer damage and agronomic trait mean squares

\begin{tabular}{|c|c|c|c|c|c|c|c|c|c|c|c|c|c|c|}
\hline \multirow[b]{2}{*}{ Source $^{a}$} & \multicolumn{2}{|r|}{ LT2 } & \multicolumn{2}{|c|}{ NT2 } & \multicolumn{2}{|r|}{ LD1 } & \multicolumn{2}{|r|}{ Silk } & \multicolumn{2}{|c|}{ Tassel } & \multicolumn{2}{|r|}{ PHT } & \multicolumn{2}{|c|}{ EHT } \\
\hline & $\mathrm{df}$ & MS & df & MS & df & MS & df & MS & $\mathrm{df}$ & MS & df & MS & $\mathrm{df}$ & MS \\
\hline $\mathrm{E}$ & 9 & $3,496 * * *$ & 9 & $216^{* * *}$ & 10 & $8.78 * * *$ & 4 & $942.3 * * *$ & 3 & $383.6 * * *$ & 5 & $59,981 * * *$ & 5 & $1,482 * * *$ \\
\hline G & 11 & $2,123 * * *$ & 11 & 109 **** & 11 & $24.41 * * *$ & 11 & $63.2 * * *$ & 11 & $47.6 * * *$ & 11 & 8,939 *** & 11 & $2,798 * * *$ \\
\hline $\mathrm{G}^{*} \mathrm{E}$ & 99 & $158 * * *$ & 99 & $10 * * *$ & 110 & $1.26 * * *$ & 44 & $3.3 * * *$ & 33 & $2.5 * * *$ & 55 & $213 * * *$ & 55 & $142 * * *$ \\
\hline $\operatorname{Rep}(\mathrm{E})$ & 21 & $176^{* * * *}$ & 21 & $5^{* * *}$ & 23 & $0.55 \mathrm{~ns}$ & 10 & $1.3 \mathrm{~ns}$ & 8 & $2.3^{*}$ & 12 & 407 *** & 12 & $151 * * *$ \\
\hline Residual & 221 & 49 & 221 & 2 & 243 & 0.39 & 107 & 1.3 & 85 & 1.0 & 128 & 83 & 128 & 47 \\
\hline
\end{tabular}

Variables include LT2 for the length of tunneling (centimeters) per plot by second generation European corn borers, NT2 for number of tunnels, LDl for first generation leaf damage score, silk for number of days to $50 \%$ silking in each plot, tassel for number of days to $50 \%$ tassels shedding in each plot, PHT for plant height (centimeters), and EHT for ear height (centimeters).

${ }^{a}$ Sources of variation include environments $(\mathrm{E})$, genotypes $(\mathrm{G})$, their interaction, and replications nested in environments, respectively. Environments and genotypes were considered as fixed effects. * and *** denote significance at $P=0.05$ and 0.001 , respectively.

lines and (2) determine the sources of the observed interactions.

\section{Materials and Methods}

A group of 12 maize lines was chosen to represent a range of resistance to European corn borer, including the susceptible checks Mo17 and B73 (Table 1). Experiments were conducted in 2002 in Stoneville and Elizabeth, MS; Columbia and Tipton, MO; Ithica, NE; Ames, IA (two distinct sites); Clinton and Pekin, IL; Wooster, OH; and Newark, DE (Table 2). Experiments were arranged in randomized complete block designs with three replications, except at Ithica, NE, which had four replications. Target plant densities were $\approx 50,000$ plants per hectare. Normal agronomic practices were followed for each environment and no insecticides were applied.

Larval Infestation. First generation European corn borer infestation was performed at the 8- to 10-leaf stage. The USDA-ARS Corn Insects and Crop Genetics Research Unit (Ames, IA) supplied eggs for all environments except Illinois. Garst Seed Company (Slater, IA), supplied eggs for the Illinois environments. For their supply, each summer to fall, a new colony is initiated from eggs produced by feral secondgeneration moths captured in light traps at Slater. The colony is intermated for two to three generations to

Table 4. Pearson correlation coefficients of European corn borer damage and agronomic traits

\begin{tabular}{|c|c|c|c|c|c|c|}
\hline Trait & Silk & Tassel & PHT & EHT & NT2 & LT2 \\
\hline LD1 & $-0.22 * *$ & -0.31 *** & $0.32 * *$ & $0.30 * * *$ & $0.14^{* *}$ & 0.20 ** \\
\hline Silk & & 0.93*** & $-0.41 * * *$ & $-0.01 \mathrm{~ns}$ & $0.52 * * *$ & $0.33 * * *$ \\
\hline Tassel & & & $-0.03 \mathrm{~ns}$ & 0.31 *** & $0.43 * * *$ & $0.07 \mathrm{~ns}$ \\
\hline PHT & & & & $0.60 * * *$ & $-0.03 \mathrm{~ns}$ & $-0.24 * * *$ \\
\hline EHT & & & & & $0.22 * *$ & $0.24 * * *$ \\
\hline NT2 & & & & & & $0.65^{* * * *}$ \\
\hline
\end{tabular}

Traits include LD1 for first generation leaf damage score, silk for number of days to $50 \%$ silking in each plot, tassel for number of days to $50 \%$ tassels shedding in each plot, PHT for plant height (centimeters), and EHT for ear height (centimeters), NT2 for number of tunnels per plant by second generation European corn borers, and LT2 for the length of tunneling (centimeters) per plant. $* *$ and $* * *$ denote significance at $P=0.01$ and 0.001 , respectively. minimize disease and then crossed to the stock colony at approximately a ratio of 2.5 feral: 1 stock adults. The new stock colony is built up and disinfected by heattreating eggs, and the larvae are fed a meridic diet with elevated antiparasitic additives for several generations until field use. The USDA-ARS colony is managed similarly.

Eggs were incubated, hatched, suspended in corn grits, and aliquots with 50-60 neonate larvae were dropped into the whorls of the first six plants of each plot. Infestation was repeated in 3 to $4 \mathrm{~d}$. About $3 \mathrm{wk}$ after infestation, shot-hole leaf-feeding damage on plots was visually evaluated on a 1 to 9 scale (Guthrie et al. 1960).

For second generation infestation, eggs were prepared as described above. Sixty neonate larvae were applied to the ear leaf axil and one node above on the last 11 plants of each plot when just $>50 \%$ of the plots were shedding pollen. Infestation was repeated in 3 to $5 \mathrm{~d}$. After senescence, infested plants were split from the ground and rated for the number of tunnel holes and total length of tunneling in $\mathrm{cm}$.

Agronomic Characteristics. Plots in most locations were evaluated for percentage of stand, silking, and tasseling (number of days until 50\% of the plants in a plot had silked or tasseled), plant height (centimeters from the ground to the flag leaf collar), and ear height (centimeters from the ground to the top ear's shank attachment).

Statistical Analyses. Analysis of variance (ANOVA) was performed with PROC MIXED in SAS, version 8.0 (Littell et al. 1996, SAS Institute 2002) to generate REML variance component estimates. Plot means were analyzed. Genotypes and environments were treated as fixed effects because they were selected and not necessarily representative of the population of corn genotypes or all corn-growing environments (Table 3). Pearson correlations among traits were tested with PROC CORR in SAS (Table 4). Multiple range comparisons were made on least square means for genotypes and environments by using Fisher's protected least significant difference (LSD) test (Tables 5 and 6). A design matrix was constructed to partition the variances due to environment, genotype, and GEI into their single degree of freedom 
Table 5. Least square means by environment for European corn borer damage and agronomic traits

\begin{tabular}{|c|c|c|c|c|c|c|c|c|}
\hline Environment & Code & $\mathrm{LT} 2(\mathrm{~cm})$ & NT2 no. & LDl (1-9) & Silk (d) & Tassel (d) & PHT $(\mathrm{cm})$ & $\operatorname{EHT}(\mathrm{cm})$ \\
\hline Columbia, MO & $\mathrm{E} 1$ & $30.5 \mathrm{~cd}$ & $3.2 \mathrm{~b}$ & $3.2 \mathrm{c}$ & $63.6 \mathrm{a}$ & $63.1 \mathrm{~b}$ & $183.0 \mathrm{~d}$ & $82.4 \mathrm{c}$ \\
\hline Tipton, MO & $\mathrm{E} 2$ & $25.8 \mathrm{bc}$ & $4.3 \mathrm{c}$ & $2.5 \mathrm{~b}$ & & & $144.0 \mathrm{~b}$ & $69.5 \mathrm{a}$ \\
\hline HF Ames, IA & E3 & $12.4 \mathrm{a}$ & $7.2 \mathrm{~d}$ & $3.4 \mathrm{~cd}$ & $67.6 \mathrm{~b}$ & $66.2 \mathrm{c}$ & $231.3 \mathrm{e}$ & $80.9 \mathrm{bc}$ \\
\hline PI Ames, IA & $\mathrm{E} 4$ & $9.6 \mathrm{a}$ & $2.3 \mathrm{a}$ & $3.4 \mathrm{~cd}$ & $63.0 \mathrm{a}$ & $62.4 \mathrm{a}$ & $234.2 \mathrm{e}$ & $78.9 \mathrm{~b}$ \\
\hline Stoneville, MS & E5 & $24.9 \mathrm{bc}$ & $4.6 \mathrm{c}$ & $3.5 \mathrm{~d}$ & & & & \\
\hline Elizabeth, MS & E6 & $21.8 \mathrm{~b}$ & $4.0 \mathrm{c}$ & $3.6 \mathrm{~d}$ & & & & \\
\hline Newark, DE & E7 & $23.5 \mathrm{bc}$ & $8.1 \mathrm{e}$ & $2.1 \mathrm{a}$ & $71.6 \mathrm{c}$ & $69.6 \mathrm{~d}$ & $177.6 \mathrm{c}$ & $80.3 \mathrm{bc}$ \\
\hline Wooster, $\mathrm{OH}$ & E8 & $34.1 d$ & $8.8 \mathrm{e}$ & $2.7 \mathrm{~b}$ & $75.0 \mathrm{~d}$ & & $137.1 \mathrm{a}$ & $67.2 \mathrm{a}$ \\
\hline Clinton, IL & E9 & $8.4 \mathrm{a}$ & $2.2 \mathrm{a}$ & $3.5 \mathrm{~d}$ & & & & \\
\hline Pekin, IL & E10 & $\mathrm{n} / \mathrm{a}$ & $\mathrm{n} / \mathrm{a}$ & $3.5 \mathrm{~d}$ & & & & \\
\hline Ithica, NE & E11 & $6.9 \mathrm{a}$ & $2.6 \mathrm{ab}$ & $3.5 \mathrm{~d}$ & & & & \\
\hline
\end{tabular}

Traits include LT2 for the length of tunneling per plant (centimeters) by second generation European corn borers, NT2 for number of tunnels per plant by second generation European corn borers, LD1 for first generation leaf-feeding score on a 1 (none) to 9 (very heavy) severity scale, silk for number of days to $50 \%$ silking in each plot, tassel for number of days to $50 \%$ tassels shedding in each plot, PHT for plant height (centimeters), and EHT for ear height (centimeters). Means sharing the same letter are not significantly different at $P=0.05$ by using Fisher's least significant difference test. $\mathrm{n} / \mathrm{a}$, data not available.

components with PROC GLM regression analysis (Table 7). To conform to restrictions on degrees of freedom, the nonestimated environments, genotypes, and their interactions were calculated by the orthogonal balance of their estimate sums. The F-tests of the mean squares partitioned for each effect were used to test the significance of the partial regression coefficients.

\section{Results and Discussion}

The combined analysis across environments for the length of tunneling revealed main effects for environment and genotype that were $>20$ - and 10 fold larger than their interaction effect, respectively (Table 3). Main effects also were much stronger than GEI for the number of tunnel holes and leaffeeding damage. The relative magnitude of GEI was smallest for leaf feeding damage among these three European corn borer traits. Stalk tunneling by second generation larvae is generally more reflective of yield losses than the first generation leaffeeding damage or the number of tunnels of second generation larvae (Traore et al. 2000, Baute et al. 2002).
Mean ratings for leaf-feeding damage at each environment (across genotypes) were comparable and ranged from 2.5 to 3.6 (Table 5 ). Wider variability was observed for the number of tunnel holes (2.6-8.1 tunnels per plant) as well as for total length of tunneling (6.9-30.5 cm tunneling per plant). The results did not seem to be related to environmental or weather differences (Table 2).

Length of tunneling means for genotypes (averaged across environments) ranged from 10.1 to 35.4 $\mathrm{cm}$ with an overall mean of $19.8 \mathrm{~cm}$. The five genotypes with the lowest total length of tunneling means only varied from 10.2 to $11.2 \mathrm{~cm}$ (averaged across environments), whereas the susceptible group was about double the resistant group's tunnel length means (Table 6). B73 was clearly the most susceptible with a mean of $35.4 \mathrm{~cm}$ per plant tunneling. All of the partitioned genotypic effects were highly significant, with the susceptible check B73 being the most prominent. Interestingly, we observed distinct separation of five putatively resistant genotypes into a moderately susceptible group for total length of tunneling (Table 6), including GEMS-0001, its derivative SSM34-5A91102A,

Table 6. Least square means by genotype for European corn borer damage and agronomic traits

\begin{tabular}{|c|c|c|c|c|c|c|c|c|}
\hline Genotype & No. & $\mathrm{LT} 2(\mathrm{~cm})$ & NT2 no. & LD1 (1-9) & Silk (d) & Tassel (d) & PHT $(\mathrm{cm})$ & $\mathrm{EHT}(\mathrm{cm})$ \\
\hline GEMS-0001 & G1 & $23.6 \mathrm{~b}$ & $5.7 \mathrm{de}$ & $3.2 \mathrm{c}$ & $68.6 c$ & $64.5 \mathrm{c}$ & $209.6 \mathrm{~g}$ & $84.9 \mathrm{fg}$ \\
\hline SSM34-5A91102A & $\mathrm{G} 2$ & $25.0 \mathrm{~b}$ & $6.2 \mathrm{e}$ & $2.7 \mathrm{~b}$ & $70.3 \mathrm{de}$ & $68.1 \mathrm{~g}$ & 212.3gh & $83.8 \mathrm{fg}$ \\
\hline DE811 & G3 & $22.6 \mathrm{~b}$ & $4.5 \mathrm{c}$ & $3.4 \mathrm{c}$ & $69.7 \mathrm{~d}$ & $67.9 \mathrm{fg}$ & $196.6 \mathrm{f}$ & $90.4 \mathrm{~h}$ \\
\hline Mo46 & G4 & $23.4 \mathrm{~b}$ & $5.3 \mathrm{~d}$ & $3.8 \mathrm{~d}$ & $66.7 \mathrm{~b}$ & $63.3 \mathrm{~b}$ & $175.6 \mathrm{~d}$ & $72.9 \mathrm{~d}$ \\
\hline Mo47 & G5 & $11.2 \mathrm{a}$ & $2.6 \mathrm{a}$ & $2.3 \mathrm{a}$ & $66.5 \mathrm{~b}$ & $64.7 \mathrm{c}$ & $171.5 \mathrm{~cd}$ & $64.6 \mathrm{c}$ \\
\hline PRMO2-9 S6 & G6 & $10.1 \mathrm{a}$ & $2.9 \mathrm{ab}$ & $2.8 \mathrm{~b}$ & $64.1 \mathrm{a}$ & $61.2 \mathrm{a}$ & $153.7 \mathrm{~b}$ & $59.9 \mathrm{~b}$ \\
\hline Mo48 & G7 & $13.1 \mathrm{a}$ & $3.4 \mathrm{~b}$ & $3.1 \mathrm{c}$ & $71.1 \mathrm{e}$ & $67.2 \mathrm{ef}$ & $194.7 f$ & 83.1efg \\
\hline Mo49 & G8 & $10.9 \mathrm{a}$ & $2.6 \mathrm{a}$ & $2.5 \mathrm{ab}$ & $66.4 \mathrm{~b}$ & $64.4 \mathrm{c}$ & $146.1 \mathrm{a}$ & $49.0 \mathrm{a}$ \\
\hline NE547 & G9 & $10.2 \mathrm{a}$ & $2.9 \mathrm{ab}$ & $2.2 \mathrm{a}$ & $68.3 \mathrm{~b}$ & $65.9 \mathrm{~d}$ & $167.7 \mathrm{c}$ & $80.7 \mathrm{ef}$ \\
\hline DE5 & G10 & $23.6 \mathrm{~b}$ & $6.1 \mathrm{e}$ & $2.7 \mathrm{~b}$ & $68.7 \mathrm{~b}$ & $66.7 \mathrm{de}$ & $216.9 \mathrm{~h}$ & 84.0fg \\
\hline B73 & G11 & $35.4 \mathrm{~d}$ & $8.6 f$ & $5.0 f$ & $66.8 \mathrm{~b}$ & $63.9 \mathrm{bc}$ & $187.5 \mathrm{e}$ & $86.3 \mathrm{~g}$ \\
\hline Mol7 & G12 & $28.2 \mathrm{c}$ & $6.2 \mathrm{e}$ & $4.4 \mathrm{e}$ & $70.6 \mathrm{e}$ & $66.2 \mathrm{~d}$ & $182.0 \mathrm{e}$ & $78.8 \mathrm{e}$ \\
\hline
\end{tabular}

Traits include LT2 for the length of tunneling (centimeters) per plot by second generation European corn borers, NT2 for number of tunnels, LD1 for first generation leaf-feeding score, silk for days to 50\% silking in each plot, tassel for days to $50 \%$ tassels shedding, PHT for plant height (centimeters), and EHT for ear height (centimeters).Means followed by the same letter are not significantly different at $P=0.05$ by using Fisher's least significant difference test. 
Table 7. Partial regression coefficients for estimation of length of tunneling (centimeters) damage by European corn borer by environment, genotype, and their significant interactions

\begin{tabular}{|c|c|c|c|c|}
\hline Environment & Genotype & Factor & Estimate & Significance \\
\hline & & Intercept (mean) & 19.79 & \\
\hline E1 & & Columbia, MO & 10.62 & $* * *$ \\
\hline $\mathrm{E} 2$ & & Tipton, MO & 6.24 & $* * *$ \\
\hline E3 & & HF Ames, IA & -7.42 & $* * *$ \\
\hline $\mathrm{E} 4$ & & PI Ames, IA & -10.20 & $* * *$ \\
\hline E5 & & Stoneville, MS & 5.05 & $* * *$ \\
\hline E6 & & Elizabeth, MS & 2.08 & ns \\
\hline E7 & & Newark, DE & 3.74 & $* *$ \\
\hline E8 & & Wooster, $\mathrm{OH}$ & 14.33 & $* * *$ \\
\hline E9 & & Clinton, IL & -11.47 & $* * *$ \\
\hline E11 & & Ithica, NE & -12.96 & $* * *$ \\
\hline & G1 & GEMS-0001 & 3.84 & $* *$ \\
\hline & $\mathrm{G} 2$ & SSM34-5A91102A & 5.17 & $* * *$ \\
\hline & G3 & DE811 & 2.84 & $*$ \\
\hline & G4 & Mo46 & 3.59 & $* *$ \\
\hline & G5 & Mo47 & -8.56 & $* * *$ \\
\hline & G6 & PRMO2-9 S6 & -9.66 & $* * *$ \\
\hline & G7 & Mo48 & -6.64 & $* * *$ \\
\hline & G8 & Mo49 & -8.86 & $* * *$ \\
\hline & G9 & NE547 & -9.59 & $* * *$ \\
\hline & G10 & DE5 & 3.83 & $* *$ \\
\hline & G11 & B73 & 15.59 & $* * *$ \\
\hline & G12 & Mol7 & 8.44 & $* * *$ \\
\hline $\mathrm{E} 2$ & G1 & & 8.56 & $*$ \\
\hline E5 & G1 & Crossover interaction & -11.08 & $* *$ \\
\hline E6 & G1 & Crossover interaction & -9.88 & $*$ \\
\hline E7 & G1 & & 10.13 & $*$ \\
\hline E11 & G1 & Crossover interaction & -6.07 & $* * *$ \\
\hline $\mathrm{E} 2$ & $\mathrm{G} 2$ & & 20.86 & $* * *$ \\
\hline $\mathrm{E} 8$ & $\mathrm{G} 2$ & & 9.48 & $*$ \\
\hline E5 & G3 & & 17.36 & $* * *$ \\
\hline E6 & G3 & & 20.16 & $* * *$ \\
\hline E1 & G4 & & 11.12 & $* *$ \\
\hline E1 & G5 & & -10.26 & $*$ \\
\hline E8 & G6 & & -8.53 & $*$ \\
\hline E9 & G6 & Crossover interaction & 9.31 & $*$ \\
\hline E11 & G7 & Crossover interaction & 8.49 & $*$ \\
\hline E2 & G8 & & -8.03 & $*$ \\
\hline $\mathrm{E} 8$ & G8 & & -16.96 & $* * *$ \\
\hline $\mathrm{E} 2$ & G10 & Crossover interaction & -8.03 & $*$ \\
\hline E6 & G10 & & 11.13 & $* *$ \\
\hline E11 & G11 & Crossover interaction & -14.79 & $* *$ \\
\hline $\mathrm{E} 2$ & G11 & & 10.05 & $*$ \\
\hline E7 & G11 & & 16.31 & $* * *$ \\
\hline E9 & G11 & Crossover interaction & -8.51 & $*$ \\
\hline E1 & G12 & & 13.21 & $* *$ \\
\hline E6 & G12 & Crossover interaction & -8.38 & $*$ \\
\hline $\mathrm{E} 8$ & G12 & & 14.17 & $* *$ \\
\hline
\end{tabular}

To conform to restrictions on degrees of freedom, the non-estimated environments (E11), genotypes (G12), and their interactions were calculated by the orthogonal balance of their estimate sums. *, **, and *** denote significance at $P \leq 0.05,0.01$, and 0.001 , respectively.

DE811, Mo46, and DE5, which were all bred for first and second generation resistance. Some of the GEI effect on European corn borer damage could simply have been due to GEI effects on plant phenology. Agronomic characteristics such as plant height, ear height, and the synchrony of days to silking and tasseling contribute to the adaptability of cultivars to a particular location. Factors affecting these characters also could affect resistance to corn borer.

A correlation to note is the number of days to silking with number of tunnel holes $(r=0.52, P<0.001)$ (Table 4). However, the correlation of number of days to silking with total length of tunneling was smaller $(r=0.33, P<0.001)$. Later flowering was associated with more tunnel holes and somewhat more tunnel length. The correlation probably has more to do with the delayed maturity of later silking inbreds giving the insects a fuller opportunity to develop. The maturity spread of the inbreds was only $5 \mathrm{~d}$, and pollen spreads to all plots such that the larvae should have had adequate food supplementation for establishment. Plant height and ear height were not correlated with European corn borer feeding damage. As expected, number of tunnel holes and total length of tunneling were positively correlated $(r=0.62, P<$ $0.0001)$. 
Table 8. Least square means by genotypes and environments (columns) for second generation European corn borer length of tunneling in centimeters

\begin{tabular}{|c|c|c|c|c|c|c|c|c|c|c|}
\hline $\begin{array}{l}\text { Genotype } \\
\text { code }\end{array}$ & E1 & E2 & E3 & $\mathrm{E} 4$ & E5 & E6 & E7 & E8 & E9 & E11 \\
\hline Gl & $34.9 \mathrm{~cd}$ & $38.4 \mathrm{~d}$ & 15.6ab & 13.1abc & 17.6ab & $15.8 \mathrm{ab}$ & $37.5 \mathrm{~d}$ & $45.7 \mathrm{def}$ & $13.0 \mathrm{ab}$ & $4.6 \mathrm{ab}$ \\
\hline $\mathrm{G} 2$ & $31.9 \mathrm{c}$ & $49.9 \mathrm{e}$ & $13.7 \mathrm{ab}$ & $11.3 \mathrm{abc}$ & $25.1 \mathrm{bcd}$ & $23.2 \mathrm{~b}$ & $26.3 \mathrm{~cd}$ & $48.8 \mathrm{ef}$ & $6.4 \mathrm{ab}$ & $13.3 \mathrm{ab}$ \\
\hline G3 & $28.4 \mathrm{bc}$ & $23.5 \mathrm{c}$ & 9.7ab & $8.5 \mathrm{ab}$ & $45.0 \mathrm{f}$ & $44.9 \mathrm{c}$ & $21.8 \mathrm{abc}$ & $34.4 \mathrm{~cd}$ & $7.4 \mathrm{ab}$ & $2.9 \mathrm{a}$ \\
\hline G4 & 45.1de & $21.9 \mathrm{abc}$ & $16.5 \mathrm{~b}$ & $17.1 \mathrm{bc}$ & $29.0 \mathrm{cde}$ & $22.5 b$ & $22.9 \mathrm{bc}$ & $36.4 \mathrm{~cd}$ & $7.8 \mathrm{ab}$ & $14.6 \mathrm{~b}$ \\
\hline G5 & $11.6 \mathrm{a}$ & $10.8 \mathrm{ab}$ & 7.6ab & $2.9 \mathrm{a}$ & $18.5 \mathrm{abc}$ & $17.4 \mathrm{ab}$ & $12.4 \mathrm{ab}$ & $21.3 \mathrm{~b}$ & $5.9 \mathrm{ab}$ & $4.0 \mathrm{ab}$ \\
\hline G6 & $16.8 \mathrm{a}$ & $14.0 \mathrm{abc}$ & $8.1 \mathrm{ab}$ & $4.4 \mathrm{a}$ & $11.2 \mathrm{a}$ & $8.4 \mathrm{a}$ & $12.1 \mathrm{ab}$ & $15.9 \mathrm{ab}$ & $8.0 \mathrm{ab}$ & $2.5 \mathrm{a}$ \\
\hline G7 & $17.6 \mathrm{ab}$ & 19.0abc & 7.0ab & $2.2 \mathrm{a}$ & $25.4 \mathrm{bcd}$ & $9.0 \mathrm{a}$ & $12.0 \mathrm{ab}$ & $26.6 \mathrm{bc}$ & $4.1 \mathrm{a}$ & $8.7 \mathrm{ab}$ \\
\hline G8 & $28.8 \mathrm{bc}$ & $9.1 \mathrm{a}$ & $4.8 \mathrm{a}$ & $5.9 \mathrm{ab}$ & $13.2 \mathrm{a}$ & $18.1 \mathrm{ab}$ & $11.0 \mathrm{a}$ & $8.3 \mathrm{a}$ & $5.8 \mathrm{ab}$ & $4.2 \mathrm{ab}$ \\
\hline G9 & $19.0 \mathrm{ab}$ & $13.9 \mathrm{abc}$ & $6.0 \mathrm{ab}$ & $5.0 \mathrm{a}$ & $13.2 \mathrm{a}$ & $8.4 \mathrm{a}$ & $12.1 \mathrm{ab}$ & $18.8 \mathrm{ab}$ & $3.7 \mathrm{a}$ & $2.1 \mathrm{a}$ \\
\hline G10 & $34.0 \mathrm{c}$ & $21.8 \mathrm{abc}$ & $16.4 \mathrm{~b}$ & $12.5 \mathrm{abc}$ & 27.4 bcde & $36.8 \mathrm{c}$ & $26.8 \mathrm{~cd}$ & 41.8de & $11.0 \mathrm{ab}$ & $7.6 \mathrm{ab}$ \\
\hline G11 & 46.5de & $51.7 \mathrm{e}$ & $28.6 c$ & $20.0 \mathrm{c}$ & $38.3 \mathrm{ef}$ & $35.7 \mathrm{c}$ & $55.4 \mathrm{e}$ & $54.7 \mathrm{f}$ & $15.4 \mathrm{~b}$ & $7.6 \mathrm{ab}$ \\
\hline G12 & $52.1 \mathrm{de}$ & $36.1 \mathrm{~d}$ & $14.4 \mathrm{ab}$ & $12.2 \mathrm{abc}$ & $34.7 \mathrm{def}$ & $21.9 \mathrm{~b}$ & $32.0 \mathrm{~cd}$ & $56.7 \mathrm{f}$ & $11.8 \mathrm{ab}$ & $10.4 \mathrm{ab}$ \\
\hline
\end{tabular}

Within columns, genotypes followed by the same letter are not significantly different at $P \leq 0.05$.

Some noncrossover reactions would likely result in selection differences between some environments. For example, in both Mississippi environments (E5 and E6), DE811 (G3) was considerably more susceptible than it was elsewhere (Tables 7 and 8). GEMS-0001 (G1) was grouped with the more resistant genotypes for total length of tunneling in the four environments that averaged the least damage, whereas it was grouped with the susceptible material in the four environments that averaged the greatest damage. This suggests that adequate infestation is necessary to identify truly resistant material that will remain relatively resistant even under high insect pressure. Despite the crossover interactions observed for B73, it still consistently grouped with the most susceptible genotypes. SSM34-5A91102A, Mo17, Mo46, and DE5 were inconsistent in their level of resistance to tunneling. This was more apparent in scanning their multiple range groupings (Table 8) than the occurrence of significant interaction effects involving G2, G4, G10, and G12, respectively (Table 7). Romagosa and Fox (1993) noted that most breeders do not perform any kind of stability analysis, but study their data closely and apply knowledge of the particular environments and genotypes to the selection process.

Elizabeth, MS, and Clinton, IL (which had the lowest length of tunneling means), were involved in two significant crossover interactions each, and the Ithica, NE, site had three. This indicates that European corn borer screening at these sites would not necessarily apply to other locations and vice versa, whether due to small differences in experimental conduct and/or environmental effects. Bohn et al. (1999) observed similar error variances and high repeatabilities for environments in Germany with high levels of natural and manual infestation.

The findings suggest that breeders may undertake several courses of action to better manage environmental effects when breeding maize for European corn borer resistance. Advanced breeding lines and potential cultivars should be tested in a wide range of environments. Breeders may optimize allocation of field testing resources by examining variance due to environments and GEI (Johnson et al. 1992). It may be useful to partition the target population of environments into smaller, less variable subgroups. Final cultivar recommendations might then be tailored to optimize genotypic performance in a particular region. Identification of subsets of specific germplasm that do not demonstrate GEI would be most desirable for breeding programs targeting broad regions. However, awareness of the bestsuited genotypes in specific environments could maximize performance in smaller more homogeneous regions. Hybrids are expected to show more yield stability and less GEI than inbreds due to their enhanced ability to withstand stress (Allard and Bradshaw 1964). This effect was observed for European corn borer resistance (Nyhus et al. 1989) in testing synthetics from several cycles of recurrent selection and their testcrosses with an inbred. They also observed more genetic gain for second versus first generation resistance.

In conclusion, GEI for reaction to European corn borer was observed in this study. The means across environments revealed genotype rankings considerably different than rankings for many individual environments with some environments and genotypes being more inconsistent with the overall mean. Environments with greater damage pushed some genotypes with moderate resistance into a susceptible range. Because all environments except Illinois used larvae from the Ames, IA, USDA-ARS insectary, and these environments differed in damage intensity and rankings, it is unlikely that insect biotype was a factor contributing to GEI. Differences in environment and small, inevitable differences in experimental details often produce GEI. A moderately, broadly based screening program is recommended to ensure consistent resistance to European corn borer. 


\section{Acknowledgments}

We acknowledge Candice Gardner (USDA-ARS North Central Regional Plant Introduction Station) for observations on GEI for European corn borer. Jean Dyer (USDA-ARS Corn Insects and Crop Genetics Research Unit) supplied European corn borer eggs for the sites noted. The key role of all of the technicians is valued, including A. Q. Antonio (Missouri), Julie Barry (Missouri), James Robbins (Iowa), Penny Meyerholtz (Iowa), Jeffrey Krumm (Nebraska), Mark Casey (Ohio), and Melanie Pollan (Mississippi). Mark Ellersieck and Ahma Asfaw (University of Missouri, Agricultural Experiment Station) provided guidance in partitioning factorial variances.

\section{References Cited}

Abel, C. A., and R. L. Wilson. 1999. Evaluation of 11 maize populations from Peru for mechanisms of resistance to leaf feeding by European corn borer. J. Kans. Entomol. Soc. 72: 149-159.

Abel, C. A., L. M. Pollak, W. Salhuana, M. P. Widrlechner, and R. L. Wilson. 2001. Registration of GEMS-0001 maize germplasm resistant to leaf blade, leaf sheath, and collar feeding by European corn borer. Crop Sci. 41: 1651-1652.

Allard, R. W., and A. D. Bradshaw. 1964. Implications of genotype-environmental interactions in applied plant breeding. Crop Sci. 4: 503-507.

Barry, D., M. S. Zuber, and L. L. Darrah. 1985. Registration of Mo-2 ECB-2 maize germplasm. Crop Sci. 25: 715-716.

Barry, D., A. Q. Antonio, and L. L. Darrah. 1995. Registration of Mo45, Mo46, and Mo47 maize germplasm lines with resistance to European corn borer. Crop Sci. 35: 1232-1233.

Baute, T. S., M. K. Sears, and A. W. Schaafsma. 2002. Use of transgenic Bacillus thuringiensis Berliner corn hybrids to determine the direct economic impact of the European corn borer (Lepidoptera: Crambidae) on field corn in eastern Canada. J. Econ. Entomol. 95: 57-64.

Bode, W. M., and D. D. Calvin. 1990. Yield-loss relationships and economic injury levels for European corn borer (Lepidoptera: Pyralidae) populations infesting Pennsylvania field corn. J. Econ. Entomol. 83: 1595-1603.

Bohn, M., R. C. Kreps, D. Klein, and A. E. Melchinger. 1999. Damage and grain yield losses caused by European corn borer (Lepidoptera: Pyralidae) in early maturing European maize hybrids. J. Econ. Entomol. 92: 723-731.

Cardinal, A. J., M. Lee, N. Sharopova, W. L. WoodmanClikeman, and M. J. Long. 2001. Genetic mapping and analysis of quantitative trait loci for resistance to stalk tunneling by the European corn borer in maize. Crop Sci. 41: $835-845$.

Crossa, J. 1990. Statistical analyses of multi-location trials. Adv. Agron. 44: 55-85.

Davis, P. M., and L. P. Pedigo. 1991. Economic injury levels for management of stalk borer (Lepidoptera: Noctuidae) in corn. J. Econ. Entomol. 84: 290-293.

D’Croz-Mason, N. E., S. C. Mason, and J. E. Foster. 2002. Registration of N547 maize germplasm line. Crop Sci. 42: 312.

Gatch, E. W., and G. P. Munkvold. 2002. Fungal species composition in maize stalks in relation to European corn borer injury and transgenic insect protection. Plant Dis. 86: $1156-1162$.

Godfrey, L. D., T. O. Holtzer, S. M. Spomer, and J. M. Norman. 1991. European corn borer (Lepidoptera:
Pyralidae) tunneling an drought stress: effects on corn yield. J. Econ. Entomol. 84: 1850-1860.

Guthrie, W. D., F. F. Dicke, and C. R. Neiswander. 1960. Leaf and sheath feeding resistance to the European corn borer in eight inbred lines of dent corn. Ohio Agric. Exp. Stn. Bull. 860. Wooster, OH.

Guthrie, W. D., and W. A. Russell. 1989. Breeding methodologies and genetic basis of resistance in maize to the European corn borer, pp. 192-202. In Toward Insect Resistant Maize for the Third World. Proceedings of the International Symposium on Methodologies for Developing Host Plant Resistance to Maize Insects. CIMMYT, Mexico, D.F., Mexico.

Hawk, J. A. 1985. Registration of DE811 germplasm line of maize. Crop Sci. 25: 716.

Jampatong, C., M. D. McMullen, B. D. Barry, L. L. Darrah, P. F. Byrne, and H. Kross. 2002. Quantitative trait loci for first- and second-generation European corn borer resistance derived from the maize inbred Mo47. Crop Sci. 42: 584-593.

Johnson, J. J., J. R. Alldredge, S. E. Ullrich, and O. Dangi. 1992. Replacement of replications with additional locations for grain sorghum cultivar evaluations. Crop Sci. 3. 2: $43-46$.

Littell, R. C., G. A. Milliken, W. W. Stroup, and R. Wolfinger. 1996. SAS system for mixed models. SAS Publishing, Cary, NC.

Magg, T., A. E. Melchinger, D. Klein, and M. Bohn. 2002. Relationship between European corn borer resistance and concentration of mycotoxins produced by Fusarium spp. in grains of transgenic Bt maize hybrids, their isogenic counterparts, and commercial varieties. Plant Breed. 121: 146-154.

Martin, M. A., and J. Hyde. 2001. Economic consideration for the adoption of transgenic crops: the case of Bt corn. J. Nematol. 33: 173-177.

Mason, C. E., M. E. Rice, D. D. Calvin, J. W. Van Duyn, W. B. Showers, W. D. Hutchinson, J. F. Witkowski, R. A. Hig gins, D. W. Onstad, and G. P. Dively. 1996. European corn borer: ecology and management. North Central Region Ext. Publ. No. 327. Iowa State University, Ames, IA

Nyhus, K. A., W. A. Russell, and W. D. Guthrie. 1989. Changes in agronomic traits associated with recurrent selection in two maize synthetics. Crop Sci. 29: 269-275.

Romagosa, I., and P. N. Fox. 1993. Genotype $\times$ environment interaction and adaptation, pp. 373-390. In M. D. Hayward, N. O. Bosemark, and I. Romagosa (eds.), Plant breeding: principles and prospects. Chapman \& Hall, London.

Russell, W. A. 1972. Registration of B70 and B73 parental lines of maize. Crop Sci. 12: 721.

SAS Institute. 2002. SAS proprietary software release 8.02 SAS Institute, Cary, NC.

Traore, S. B., R. E. Carlson, C. D. Pilcher, and M. E. Rice. 2000. Bt and non-Bt maize growth and development as affected by temperature and drought stress. Agron. J. 92: $1027-1035$.

Yang, R.-C. 2002. Likelihood-based analysis of genotype-environment interaction. Crop Sci. 42:1434-1440.

Zuber, M. S. 1973. Registration of 20 maize parental lines. Crop Sci. 13: 779 . 2004
Received for publication 5 January 2004; accepted 1 July Rece 